\title{
TO THE STUDY OF APHYLLOPHOROID FUNGI (AGARICOMYCETES, BASIDIOMYCOTA) IN SHEBEKINSKY DISTRICT, BELGOROD REGION
}

\author{
(C) S. V. Volobuev \\ С. В. Волобуев \\ К изучению афиллофороидных грибов (Agaricomycetes, Basidiomycota) \\ Шебекинского района Белгородской области \\ ФГБУН Ботанический институт им. В. Л. Комарова РАН \\ 197376, Россия, г. Санкт-Петербург, ул. проф. Попова, д. 2. Тел.: +7 (812) 372-54-69, e-mail: sergvolobuev@binran.ru
}

\begin{abstract}
The article presents an annotated list of 40 species of aphyllophoroid fungi revealed in Shebekinsky district of the Belgorod Region in August 2019. Twenty-one of the species are new to the Belgorod Region (including Dendrothele alliacea, Dichomitus squalens, Hydnoporia tabacina, Hyphodontia pallidula, Kneiffiella subalutacea, Lentinus arcularius, Leptosporomyces galzinii, Meruliopsis taxicola, Mucronella calva, Peniophora incarnata, Phanerochaete alnea, Tubulicrinis calothrix, Xylodon asperus, etc.). Most of the revealed species (70\%) were found on the dead wood of Pinus sylvestris which is the main forest-forming tree on the studied territory. The species Leptoporus mollis is strongly recommended to be included into the Red Data Book of the Belgorod Region.

Keywords: aphyllophoroid fungi, biodiversity, Leptoporus mollis, distribution of fungi, regional protected areas, Central Russian Upland.
\end{abstract}

Аннотация. Представлен аннотированный список из 40 видов афиллофороидных грибов, выявленных в августе 2019 г. в пределах региональной ООПТ Белгородской области «Кварталы N 12, 13, 14, 18, 19, 20 Архангельского участка Шебекинского лесничества». Впервые для Белгородской области указывается 21 вид грибов, в том числе Dendrothele alliacea, Dichomitus squalens, Hydnoporia tabacina, Hyphodontia pallidula, Kneiffiella subalutacea, Lentinus arcularius, Leptosporomyces galzinii, Meruliopsis taxicola, Mucronella calva, Peniophora incarnata, Phanerochaete alnea, Tubulicrinis calothrix, Xylodon asperus и другие. Большинство видов грибов (70\%) выявлено на древесине Pinus sylvestris, являющейся основной лесообразующей древесной породой на обследованной территории. Вид Leptoporus mollis рекомендован для включения в Красную книгу Белгородской области.

Ключевые слова: афиллофороидные грибы, биоразнообразие, Leptoporus mollis, распространение грибов, региональные ООПТ, Среднерусская возвышенность.

DOI: $10.22281 / 2686-9713-2019-3-21-25$

\section{Introduction}

Aphyllophoroid fungi represent the non-taxonomic group of basidiomycetes, which are the key dead wood decomposers, with the exception of some ectomycorrhizal representatives, and are predominantly associated with forest ecosystems (Bondartseva, 2000). A number of regions in the center and the south of European Russia are characterized by sparse forest areas that have been undergoing continuous fragmentation for several centuries. The Belgorod Region, located in the southwestern part of the Central Russian Upland, is one of the regions of the forest-steppe zone, where forest ecosystems have been preserved mostly within the boundaries of specially protected natural areas. To date, 170 species of aphyllophoroid fungi have been registered in the Belgorod Region (Brezhnev, 1950; Ryabova, Ignatenko, 1981; Nikolaev, 1986; Psurtseva et al., 2003; Volobuev et al., 2015; 
Bolshakov, Volobuev, 2016; Volobuev, Bolshakov, 2016; Volobuev et al., 2019). The purpose of this survey is to obtain new data on the species diversity of aphyllophoroid fungi and the plant substrates they inhabit in the previously unexplored regionally valuable protected area in Shebekinsky district of the Belgorod Region.

\section{Materials and methods}

Collection of specimens of aphyllophoroid fungi basidiomes was made by a route method within the regionally valuable protected area «Quarters N 12, 13, 14, 18, 19, 20 of the Arkhangelsk area of Shebekinsky forestry» with a total area of $2,9 \mathrm{~km}^{2}$ in August 2019. The co-

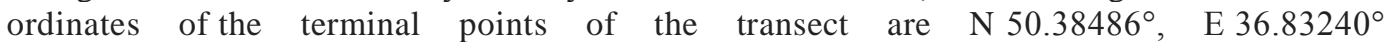
and $\mathrm{N} 50.37730^{\circ}$, E $36.83051^{\circ}$. The main forest types explored were pine-dominated forests with oak, elm, maple and hazel as well as herb-rich pine forests. Identification of the collected field materials was performed using modern methods of light microscopy. The specimens are deposited in the Mycological Herbarium of the Komarov Botanical Institute of the Russian Academy of Sciences (LE) and the mycological collection of the V. N. Khitrovo Herbarium of the Oryol State University named after I. S. Turgenev (OHHI).

\section{Results and discussion}

All of 40 species of aphyllophoroid fungi were registered on the territory studied. The annotated list of species with types of occupied substrates, host plants and herbariums' collection numbers is presented below. Names of fungal taxa are listed in the alphabetical order. Names of fungal taxa are given according to the Index Fungorum (2019) and are listed in the alphabetical order. New for the Belgorod Region species are marked with an asterisk (*). Names of vascular plants are given according to P. F. Maevsky (2014).

Auriscalpium vulgare Gray - on fallen cones of Pinus sylvestris, LE 314153.

*Botryobasidium subcoronatum (Höhn. \& Litsch.) Donk - on fallen trunk of Pinus sylvestris, LE 314135.

Byssomerulius corium (Pers.) Parmasto - on dry branches of Malus sylvestris, LE 314147.

*Dendrothele alliacea (Quél.) P. A. Lemke - on dry branches of Ulmus sp., LE 314145.

*Dichomitus squalens (P. Karst.) D. A. Reid - on fallen trunk of Pinus sylvestris, LE 314131.

Fomitiporia punctata (P. Karst.) Murrill - on fallen trunk of Prunus padus, LE 314144.

*Gloeophyllum sepiarium (Wulfen) P. Karst. - on fallen trunk of Pinus sylvestris, LE 314159.

*Hydnoporia tabacina (Sowerby) Spirin, Miettinen \& K. H. Larss. - on dry branches of Malus sylvestris, LE 314157.

Hyphoderma setigerum (Fr.) Donk - on fallen trunks of Pinus sylvestris and on a dry standing tree of Quercus robur, LE 314132, LE 314148, OHHI 1434.

*Hyphodontia pallidula (Bres.) J. Erikss. - on fallen trunks and stumps of Pinus sylvestris, LE 314140, LE 314143.

*Kneiffiella subalutacea (P. Karst.) Jülich \& Stalpers - on fallen trunk of Pinus sylvestris, LE 314121.

*Lentinus arcularius (Batsch) Zmitr. - on fallen branches of Quercus robur, LE 314161.

*Leptoporus mollis (Pers.) Quél. - on fallen trunk of Pinus sylvestris, LE 314160. Fig. 1.

*Leptosporomyces galzinii (Bourdot) Jülich - on fallen trunk of Pinus sylvestris, LE 314122.

Lyomyces crustosus (Pers.) P. Karst. [三Xylodon crustosus (Pers.) Chevall.] - on dry branches of Ulmus sp., LE 314146.

*Meruliopsis taxicola (Pers.) Bondartsev - on fallen trunk of Pinus sylvestris, LE 314141.

*Mucronella calva (Alb. \& Schwein.) Fr. - on fallen trunk of Pinus sylvestris, LE 314138. 
Neofavolus alveolaris (DC.) Sotome \& T. Hatt. [三 Polyporus alveolaris (DC.) Bondartsev \& Singer] - on fallen branch of Acer platanoides, LE 314154.

Peniophora cinerea (Pers.) Cooke - on dry branches of Pyrus communis, LE 314156.

*Peniophora incarnata (Pers.) P. Karst. - on dry branch of Prunus armeniaca, LE 314158.

Peniophora quercina (Pers.) Cooke - on dry standing tree of Quercus robur, LE 314149.

Peniophorella pubera (Fr.) P. Karst. - on fallen trunks of Pinus sylvestris, LE 314139, OHHI 1438.

*Phanerochaete alnea (Fr.) P. Karst. - on fallen trunk of Pinus sylvestris, LE 314152.

*Phanerochaete sanguinea (Fr.) Pouzar - on fallen trunk of Pinus sylvestris, LE 314123.

*Phanerochaete sordida (P. Karst.) J. Erikss. \& Ryvarden - on fallen branches of Pinus sylvestris, LE 314133.

Phlebiopsis gigantea (Fr.) Jülich - on stumps of Pinus sylvestris, LE 314142, OHHI 1440.

Postia leucomallella (Murrill) Jülich [三Oligoporus leucomallellus (Murrill) Gilb. \& Ryvarden] - on fallen trunk of Pinus sylvestris, LE 314129.

*Skeletocutis carneogrisea A. David - on fallen trunks of Pinus sylvestris and on dead basidiomes of Trichaptum fuscoviolaceum, LE 314137, OHHI 1442.

Stereum sanguinolentum (Alb. \& Schwein.) Fr. - on fallen trunk of Pinus sylvestris, LE 314124.

Thelephora terrestris Ehrh. - on fallen trunk of Pinus sylvestris, LE 314151.

*Tomentella radiosa (P. Karst.) Rick - on fallen trunk of Pinus sylvestris, LE 314125.

Trametes ochracea (Pers.) Gilb. \& Ryvarden - on fallen branch of Salix caprea, LE 314155.

Trichaptum fuscoviolaceum (Ehrenb.) Ryvarden - on fallen trunk of Pinus sylvestris.

*Tubulicrinis calothrix (Pat.) Donk - on fallen trunk of Pinus sylvestris, LE 314136.

Vuilleminia comedens (Nees) Maire - on dry branches of Quercus robur, LE 314150.

*Xylodon asperus (Fr.) Hjortstam \& Ryvarden - on fallen trunks of Pinus sylvestris, LE 314130, OHHI 1435, OHHI 1441.

*Xylodon brevisetus (P. Karst.) Hjortstam \& Ryvarden - on fallen branches of Pinus sylvestris, LE 314126.

Xylodon nespori (Bres.) Hjortstam \& Ryvarden - on fallen trunks and branches of Pinus sylvestris, LE 314127, OHHI 1437.

Xylodon raduloides Riebesehl \& Langer [三 Schizopora radula (Pers.) Hallenb.]- on fallen branches of Pinus sylvestris, LE 314128.

Xylodon spathulatus (Schrad.) Kuntze - on fallen trunks of Pinus sylvestris, LE 314134, OHHI 1436, OHHI 1439.

Most of the species (28 species, or $70 \%$ ) are found on Pinus sylvestris, which is the main forest-forming tree in the studied area. The presence of pine has determined the occurrence of such species as Auriscalpium vulgare, Dichomitus squalens, Hyphodontia pallidula, Phanerochaete sanguinea, Skeletocutis carneogrisea, etc., associated with coniferous trees. Among them, several fungal species (Postia leucomallella, Trichaptum fuscoviolaceum, Xylodon asper$u s$ ) were also registered in forest-steppe zone of the Central Russian Upland on the territory of the Oryol Region (Volobuev, 2013).

The most remarkable species for conservation purpose is presented by Leptoporus mollis which is known in the European part of Russia based on records predominantly from boreal and hemiboreal forests. The occurrence of the species closest to our find is cited from the protected area of the Voronezh Biosphere Reserve (Kotkova, 2019). Ecological preferences of the species are determined by the presence of large-size dead wood of coniferous (Picea spp., Pinus spp.) and by the absence of anthropogenic habitat disturbance. The species Leptoporus mollis is strongly recommended to be considered for including into the Red Data Book of the Belgorod Region. 

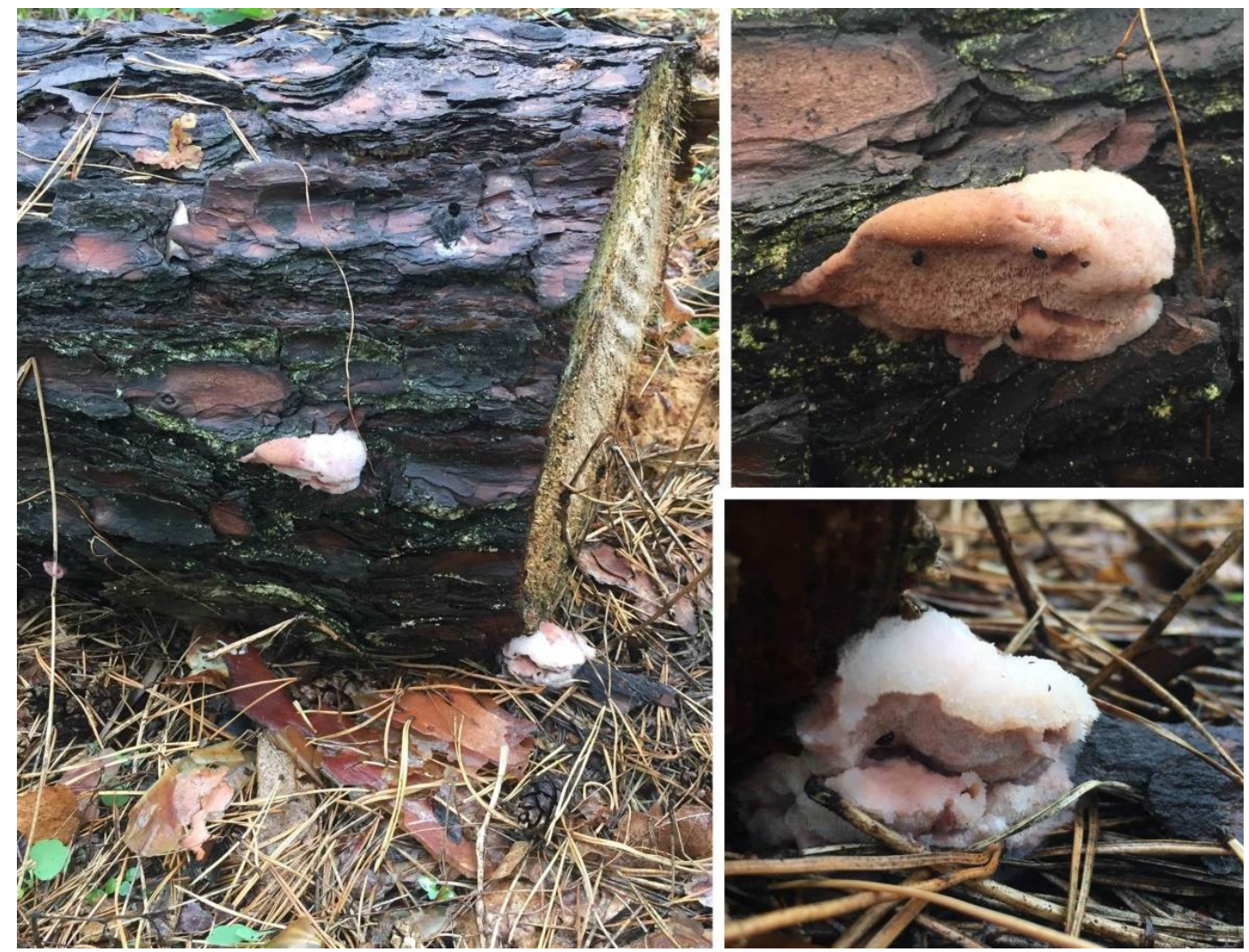

Fig. 1. Basidiocarps of Leptoporus mollis.

Рис. 1. Плодовые тела Leptoporus mollis.

\section{Conclusion}

As a result of the short-time mycological observation on the territory of Shebekinsky district of the Belgorod Region 40 species of aphyllophoroid fungi were revealed. Among them 21 species were registered for the first time in the region. The predominance of fungal species developing basidiocarps on dead wood of Pinus sylvestris is connected with the role of this plant as the main forest-forming tree.

The study was carried out within the framework of research project of the Komarov Botanical Institute RAS «Herbarium funds of the BIN RAS (history, conservation, study and supplementation)» (AAAA-A18-118022090078-2) and was financially supported by the Grant of the President of the Russian Federation for state assistance of young Russian scientists - candidates of sciences (MK-3216.2019.11).

\section{References}

Bolshakov S. Yu., Volobuev S. V. 2016. New data on aphyllophoroid fungi of the Yamskaya Steppe («Belogorye» Nature Reserve, Belgorod region) // Bulletin of Bryansk department of the Russian Botanical Society. № 2 (8). P. 18-25. [Большаков С. Ю., Волобуев С. В. 2016. Новые сведения об афиллофороидных грибах Ямской степи (заповедник «Белогорье», Белгородская область) // Бюл. Брянского отделения Русского ботанического общества. № 2 (8). С. 18-25.]

Bondartseva M. A. 2000. Ecological and biological patterns of functioning of xylotrophic basidiomycetes in forest ecosystems // Fungal communities in forest ecosystems / Proceedings of coordinating studies. Moscow; Petrozavodsk: Karelian Scientific Center of RAS. P. 9-25. [Бондариева M. A. 2000. Эколого-биологические закономерности функциони- 
рования ксилотрофных базидиомицетов в лесных экосистемах // Грибные сообщества лесных экосистем: Мат. координационных исследований. М., Петрозаводск: КарНЦ РАН. С. 9-25.]

Brezhnev I. E. 1950. Parazitnaia i saprofitnaia mikoflora drevesnykh i kustarnikovykh porod polezashchitnykh lesnykh polos // Uch. Zap. Leningradskogo gos. un-ta. № 134. Ser. biol. nauk. Vyp. 25 / Tr. lesostepnoy nauchno-issledovatelskoy stantsii «Les na Vorskle». Vol. 3. Р. 70-129. [Брежнев И. Е. 1950. Паразитная и сапрофитная микофлора древесных и кустарниковых пород полезащитных лесных полос // Уч. зап. Ленинградского гос. ун-та. № 134. Сер. биол. наук. Вып. 25. / Тр. лесостепной науч.-иссл. станции «Лес на Ворскле». Т. 3. С. 70-129.]

Index Fungorum [Electronic resource]. URL: http://www.indexfungorum.org/. Date of access: 29.10.2019.

Kotkova V. M. 2019. New data on aphyllophoroid fungi (Basidiomycota) of Voronezh State Natural Biosphere Reserve (Voronezh Region) // Vestnik Tverskogo gos. un-ta. Ser.: Biologiya i ekologiya. № 2 (54). P. 195-210. [Kоткова B. M. 2019. Новые сведения об афиллофоровых грибах Воронежского государственного природного биосферного заповедника (Воронежская область) // Вестник Тверского гос. ун-та. Сер.: Биология и экология. № 2 (54). С. 195-210.] https://doi.org/10.26456/vtbio83

Maevskii P. F. 2014. Flora srednei polosy evropeiskoi chasti Rossii. Izd. 11-e, ispr. i dop. M. 635 p. [Маевский П. Ф. 2014. Флора средней полосы европейской части России. Изд. 11-е, испр. и доп. М. 635 с.]

Nikolaev P. M. 1986. Mikoflora duba v zapovednike «Les na Vorskle» // Kompleksnye issledovaniia biogeotsenozov lesostepnykh dubrav. L. P. 63-74. [Николаев П. М. 1986. Микофлора дуба в заповеднике «Лес на Ворскле»// Комплексные исследования биогеоценозов лесостепных дубрав. Л. С. 63-74.]

Psurtseva N. V., Belova N. V., Ryabusheva Yu. V. 2003. Macromycetes of the Belogor'e nature reserve (plot «Les na Vorskle»). Conservation ex situ // Mikologiya i fitopatologiya. Vol. 37. Issue 6. P. 66-73. [Псуриева Н. В., Белова Н. В., Рябушева Ю. В. 2003. Макромицеты заповедника «Белогорье» (участок «Лес на Ворскле»). Сохранение ex situ // Микология и фитопатология. Т. 37. Вып. 6. С. 66-73.]

Ryabova V. P., Ignatenko O. S. 1981. Materialy po flore makromitsetov Tsentral'no-Chernozemnogo zapovednika // Floristicheskiye issledovaniya v zapovednikakh RSFSR. M. P. 124-142. [Рябова В. П., Игнатенко О. С. 1981. Материалы по флоре макромицетов Центрально-Чернозёмного заповедника // Флористические исследования в заповедниках РСФСР. М. С. 124-142.]

Volobuev S. V. 2013. Aphyllophoraceous fungi of forest ecosystems in the South-East of the Orel Region // Mikologiya i fitopatologiya. Vol. 47. Issue 4. Р. 209-217. [Волобуев С. В. 2013. Афиллофоровые грибы лесных экосистем юговостока Орловской области // Микология и фитопатология. Т. 47. Вып. 4. С. 209-217.]

Volobuev S. V., Bolshakov S. Yu. 2016. Aphyllophoroid fungi of the Middle Russian Upland. 1. The history of study and some new data // Mikologiya i fitopatologiya. Vol. 50. Issue 6. P. 335-346. [Волобуев С. В., Большаков С. Ю. 2016. Афиллофороидные грибы Среднерусской возвышенности. 1. История изучения и некоторые новые данные // Микология и фитопатология. Т. 50. Вып. 6. С. 335-346.]

Volobuev S. V., Bolshakov S. Yu., Shakhova N. V. 2019. Monitoring of xylotrophic basidiomycetes - phytopathogens of fruit trees in the Belgorod region // Biological diversity of the Caucasus and the south of Russia: procee dings of the XXI International scientific conference (Magas, 15-18 November 2019). Р. 42-45. [Волобуев C. В., Большаков С. Ю., Шахова Н. В. 2019. Мониторинг ксилотрофных базидиомицетов - фитопатогенов семечковых плодовых культур в Белгородской области // Биологическое разнообразие Кавказа и юга России: мат. XXI Междунар. науч. конф. (г. Магас, 15-18 ноября 2019 г.). С. 42-45.]

Volobuev S. V., Logachev A. A., Mushnikov N. V., Okun M. V. 2015. New records of aphyllophoroid fungi (Agaricomycetes, Basidiomycota) from the Les na Vorskle area of the Belogorye Nature Reserve (Belgorod Region, Russia) // Folia Cryptog. Estonica. Fasc. 52. P. 89-93. https://doi.org/10.12697/fce.2015.52.11

\section{Сведения об авторах}

Волобуев Сергей Викторович

к. б. н., с. н. с. лаборатории систематики и географии грибов ФГБУН Ботанический институт

им. В. Л. Комарова РАН, Санкт-Петербург

E-mail: sergvolobuev@binran.ru
Volobuev Sergey Viktorovich

Ph. D. in Biological sciences, Senior Researcher

of the Laboratory of Systematics and Geography of Fungi

Komarov Botanical Institute of RAS, St. Petersburg

E-mail: sergvolobuev@binran.ru 